\title{
Remains of Shobdon Old Church, Herefordshire
}

\section{T. Wright}

To cite this article: T. Wright (1844) Remains of Shobdon Old Church, Herefordshire, Archaeological Journal, 1:1, 233-237, DOI: 10.1080/00665983.1844.10850527

To link to this article: http://dx.doi.org/10.1080/00665983.1844.10850527

曲 Published online: 10 Jul 2014.

Submit your article to this journal $₫$

View related articles 


\section{REMAINS OF SHOBDON OLD CHURCH, HEREFORDSHIRE.}

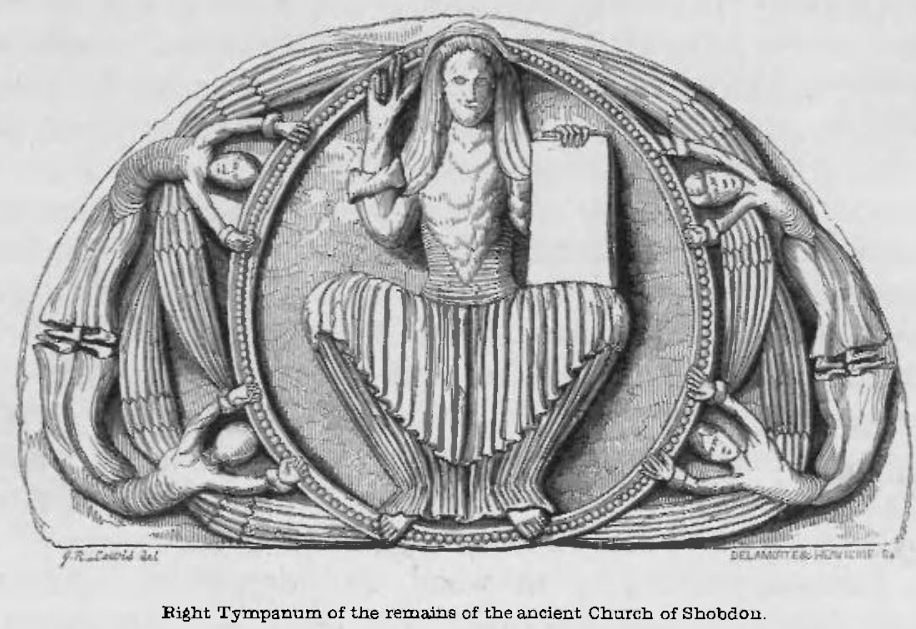

THE negligence and archæological ignorance of the last century was much more fatal to our national monuments than even the religious excitement of the period which immediately followed the Reformation. The number of early buildings, especially churches, which were sacrificed to the love of novelty, was greater than we can easily conceive. It is one of the chief objects of the British Archæological Association to put a stop to this wanton destruction, and it is conceived that this object will be more effectually secured by spreading information and a taste for the monuments of the arts of former days, than by more direct interference, except in cases where the latter is necessary to stop immediate destruction. Many interesting antiquities have escaped the danger which threatened them from the contempt of our fathers; and not a few of them, concealed in remote rural districts, have not yet met the eyes of those who are able fully to appreciate them. It is to be hoped that our Journal will be the means of bringing many of these unobserved monuments into notice, and 
with this feeling we invite our friends and correspondents to communicate drawings and descriptions of such remarkable and interesting monuments, ecclesiastical or civil, as may come under their observation.

The subject of the present paper can hardly be said to be an existing monument. Shobdon is a pretty village in Herefordshire, a few miles to the north-west of Leominster, the property of Lord Bateman. The ancient church was pulled down, (for what reason is totally unknown,) about the middle of the last century (in 1752), to give place to a new building, in which the old tower seems to have been preserved, though now almost hidden by the modern improvements. The old edifice appears to have been one of the most remarkable Norman churches in the island, and the late Lord Bateman was so struck with the singularity of its sculptured ornaments, that he caused the three principal arches to be carefully preserved and re-erected in his park, where they still remain.

The original church of Shobdon, to which these remains belonged, was built about the year $1141^{\text {a }}$, previous to which the only ecclesiastical building at Shobdon was a chapel of St. Juliana, constructed of wood, and dependant upon the neighbouring church of Aymestrey. Oliver de Merlimond, a Herefordshire knight, obtained the manor of Shobdon of the powerful lord of Wigmore, Roger de Mortimer, and having bought of the parson of Aymestrey his ecclesiastical rights over the district, he founded there a small priory, and built the edifice of which we are speaking to serve as the priory church. The fate of his monastic establishment was somewhat eventful ; amid the feuds of the border the monks were driven from one spot to another until they settled at Wigmore and grew into a famous abbey ${ }^{\mathrm{b}}$.

The remains of Shobdon church in their present state, which are interesting only as beautiful specimens of Norman ornamental sculpture, consist of three arches with their various appendages, and appear to have been reconstructed with tolerable exactness. The middle arch, which is much larger than the two others, was probably the one which sepa-

a The reasons for fixing this date are stated in the History of Ludlow and its Neighbourhood, by the writer of the present article, p. 95 , (now in the course of publication.) b Their history forms the subject of a curious narrative in Norman French, printed with a literal translation in the work just quoted. 
rated the nave from the chancel. The two smaller arches, one placed on each side of the larger arch, were perhaps the two doorways of the original building. Two tympanums, each adorned with very bold and fine bas-reliefs, are also preserved, but they do not appear to belong to the two smaller arches, if we may judge from their present appearance. That on the right of the larger arch is represented in the cut (No. 1.) at the head of this article; it represents the Deity, seated within a round aureole or glory, supported by four angels. The left tympanum contains an allegorical group of figures. The pillars supporting the arches display an extraordinary richness of ornament, of the character of which some idea may be formed from the fragments given in our woodcuts : it consists of figures of men, animals, dragons, foliage gracefully arranged, elegant knotted work, and various kinds of tracery. Our specimens are all taken

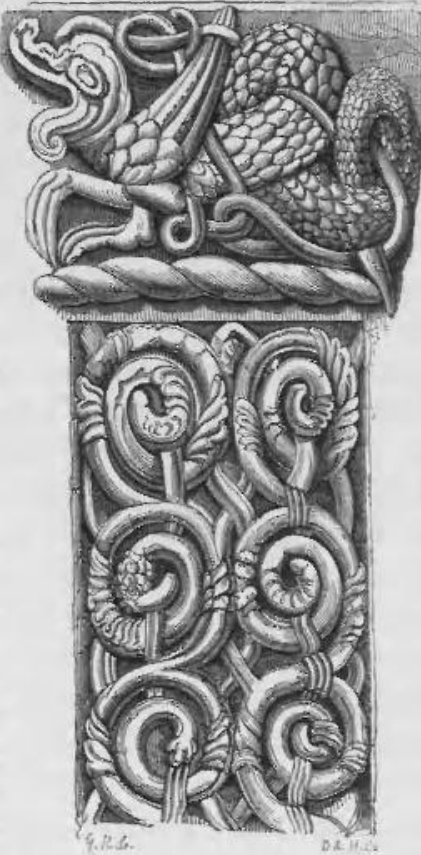

No. 2. First Piilar on the left of the lare Arch of Shobion Ghurch.

from the shafts of the middle or chancel-arch, which is supported by three pillars on each side. The first or outer pillar on the left-hand side (part of which is represented in the cut No. 2.) is a slender shaft of scroll-work, with a capital, on which is sculptured the dragon, which occurs so frequently in Anglo-Saxon and Anglo-Norman iconography. The next pillar (No. 3.) is ornamented with figures of men supposed to represent Welsh knights, arranged in couples and interwoven with tracery. Similar figures are found among the sculptures on the south door of the church of Kilpeck ${ }^{\mathrm{c}}$ on the southern

c All the sculptures of this curious church
are represented in their minutest details
in Mr. G. R. Lewis's carefully-executed
"Illustrations of Kilpeck Church." Mr.
Lewis (whose talents as an artist are uni-
versally known and appreciated) has made

a complete series of drawings of the still more remarkable ornaments of the remains of Shobdon church, from which he has kindly permitted us to select the examples given in our article. It is his intention to publish them by subscription in the same 
border of Herefordshire, and I am told that they are found on other monuments on the borders of Wales. The late Mr. Gage Rokewode called attention to the singularity of these figures as represented in the sculptures at Kilpeck, in a communication to the Society of Antiquaries in $1842^{\mathrm{d}}$, and pointed out the remarkable character of the costume. In the figures at Kilpeck church, (built about 1135, and therefore contemporary with those at Shobdon,) the cap or helmet (a sort of Phrygian bonnet) is seen to more advantage than in those at Shobdon, from the circumstance of the heads being represented in profile. The rest of the dress is precisely the same, except that in the Shobdon figures it appears to be more ornamented, and that the knotted belts of the

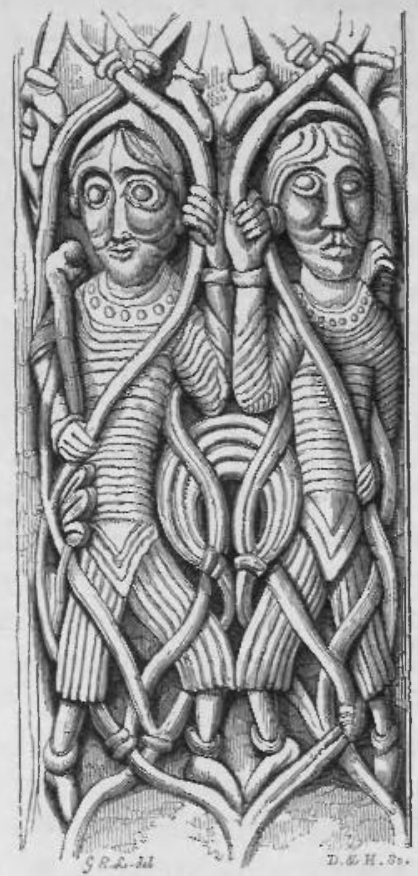
knights of Kilpeck are wanting. The two figures at Kilpeck are armed respectively with a sword and a kind of mace: one of those represented in our cut has a club, and the other Shobdon knights have similar weapons. The close vests, trousers, and shoes, are very peculiar to these figures, and of rare occurrence elsewhere. Mr. Rokewode points out some resemblance between this costume and that of the ancient Britons, as described by old writers, and as represented on some of the Roman coins of the Britannic type. The resemblance is perhaps rather imaginary than real. The third or inner pillar of the large arch at Shobdon is much larger than the others : the ornaments of the one on the right side, of which a

form as his work on Kilpeck, and we heartily wish that he may obtain a sufficient number of subscribers to enable him to put his design in execution. In a few years, these remains may have fallen into a hopeless state of dilapidation. A good work on the architectural antiquities of the churches on the borders of Wales is much wanted.

d Printed in the Archæologia, vol. xxx. p. 62. 
compartment is given in our cut No. 4 , consists of a variety

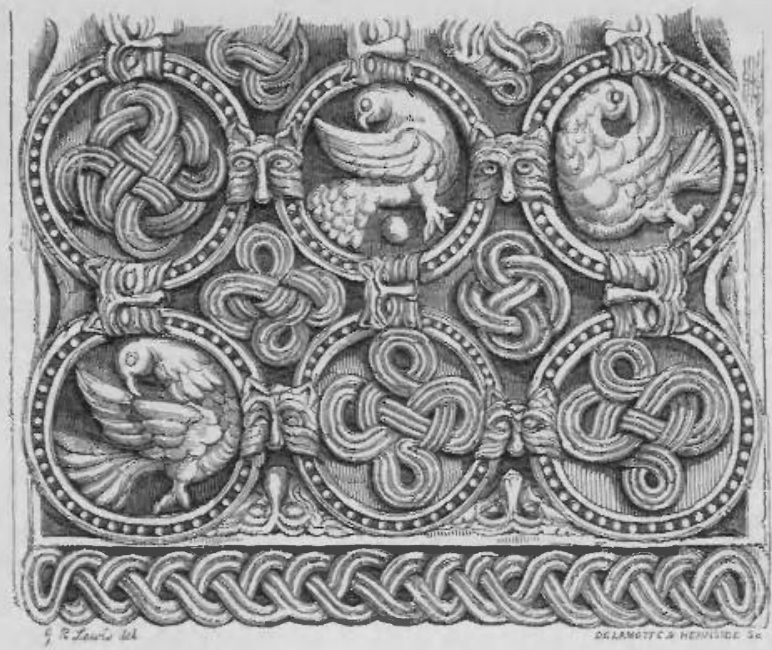

No 4. Fourth Filjar on the right of the large Arch, Shobdor Church.

of knots and animals (chiefly birds) placed within medallions, which are joined together by faces of monsters. T. WRIGHT.

\section{ON THE MEDIEVAL ECCLESIASTICAL ARCHITECTURE OF PARIS.}

\section{[FIRST PERIOD.]}

THE churches of Paris, as they now stand, afford a good school for studying the medieval architecture of the central part of France, in its various epochs ; although, taken in their several details, they cannot be compared to many edifices in the cities of the adjacent provinces. Thus, for the architecture of the thirteenth century, although there are some exquisite buildings of that date in the capital, yet there are none to compare to the cathedrals of Chartres or Rouen : and the specimens of the Flamboyant style are far superior at 